\title{
Effect of Selenium in Treatment of Male Infertility
}

\author{
Mossa M Morbat ${ }^{1}$, Azzawi M Hadi ${ }^{2 *}$ and Dekhel H Hadri ${ }^{3}$ \\ ${ }^{1}$ Department of Physiology, Tikrit Medical Collage, Iraq \\ ${ }^{2}$ Department of Surgery, Tikrit Medical Collage, Iraq \\ ${ }^{3}$ Department of Veterinary Medicine, Tikrit University, Iraq \\ *Corresponding author: Azzawi M Hadi, Department of surgery, Tikrit Medical Collage, Iraq
}

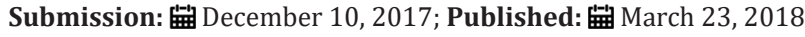

\begin{abstract}
Infertility is a problem of global proportions. The World Health Organization (WHO) estimates that 8-12\% of couples around the world experience difficulty conceiving a child. Spermatozoa like all cells living in aerobic conditions constantly face the oxygen (02) paradox. Evidence now suggests that Reactive Oxygen Species (ROS)-mediated damage to sperm is a significant contributing pathology in $30-80 \%$ of cases.

Materials and methods: A longitudinal study involves 12 infertile men were treated with Selenium capsule 50microgram (one cap.) once daily at night. The treatments continued for 3 months. History and clinical examination with semen analysis, as well as serum and seminal plasma study for zinc, magnesium, Malondialdehyde (MDA), and glutathione. FSH, LH, and Testosterone also done. All these studies done both before and after treatment. Statistical analysis done.

Results and discussion: There is significantly increase in sperm count, motility, viability, normal Sperm morphology, and ejaculate volume of infertile men compared after treatment with selenium. Serum Mg, Serum FSH, Serum LH, and Serum testosterone, and serum glutathione levels were significantly increased. Serum MDA significantly decreased in infertile men after treatment with selenium comparing with before treatment. These results supported by many studies published that explained and conclude the effect of selenium on semen quality.
\end{abstract}

Conclusion: Selenium can be used as a single agent in treatment of male infertility.

Keywords: Selenium; Male infertility; Semen analysis

\section{Introduction}

The infertility rates vary between countries and from region to regions [1]. It is documented that around $15 \%$ of married couples are infertile and that approximately $50 \%$ of infertility is due to male factor [2]. Male infertility is defined as the failure to conceive after 12 months of regular unprotected intercourse $[3,4]$. Spermatozoa like all cells living in aerobic conditions, constantly face the oxygen (02) paradox: 02 is required to support life, but its metabolites such as Reactive Oxygen Species ROS can modify cell functions, endanger cell survival or both [5]. Hence, ROS must be continuously inactivated to keep only a small amount necessary to maintain normal cell functions [6]. Malondialdehyde MDA is reactive species occurs naturally and is a marker for oxidative stress [7]. Glutathione itself also plays an important role in the protection of cells against oxidative and electrophilic stress caused by ROS and radiation $[8,9]$. Zinc salts have been shown to protect against oxidative damage and glutathione depletion in mice.

Testosterone synthesis is zinc dependent in human. The sperms take up zinc from fluid after ejaculation, therefore, zinc content of sperm cell will increase after the exposure to seminal fluid, and it affected the maturation of spermatozoa [10]. Zinc deficient diet affect oxidative stress due to decrease in glutathione \& increase in MDA in both semen \& serum [11,12]. (Se) is an essential dietary micronutrient required for maintenance of male fertility. [13] About $20-40 \%$ of male infertility is considered to be due to deficient sperm production to which selenium deficiency has been linked [14]. The biological functions associated with selenium besides male fertility include prevention of cancer, cardiovascular disease, viral mutation, endocrine and immune function as well as modulating inflammatory response [15]. Limited data is available on the effects of selenium on male reproduction. Hurst et al .reported that fertile males had significantly higher selenium levels in their seminal fluid than infertile men. This study shows the importance of selenium in male reproduction and the probable relationship between male infertility and selenium [16].

\section{Materials and Methods}

A longitudinal study in which samples were obtained from urology clinic in Tikrit teaching hospital, private clinic, from 1-112009 to 1-9-2010. A questionnaire was prepared to obtain the information from the infertile men before semen analysis which include name, age, job, smoking, marriage duration, surgical 
operation, chronic disease and genetic problem. Twelve infertile men were treated with capsules containing selenium (50micg) once daily. MDA determination is based on the colorimetric reaction with Thio Barbituric Acid (TBA) at $90-100{ }^{\circ} \mathrm{C}$ and $\mathrm{pH} 2-3$ for 15 minutes to form pink color product, which can be measured by spectrophotometer, this performed at the Central Laboratory in Tikrit University.

Semen or serum (GSH) was determined by the modified method of Tietz, 1999, and depended procedure on used Elleman's solution. Semen or serum (GSH) were performed at the Central Laboratory in Tikrit University. All the hormonal assays were performed at the Central Laboratory in Tikrit University using Enzyme-Linked Immunosorbent Assay (ELIZA) method. Zinc and magnesium concentrations in human plasma and semen were determined in North Gas Company by means of atomic-absorption spectrophotometer. Statistical analysis done.

\section{Results and Discussion}

The sperm count, motility, viability \& normal morphology are increase significantly after treatment with selenium as shown in (Table 1). Present study supported these results that low dietary intake of antioxidants (Se) and high levels of oxidizing agents in semen have been associated with decreased motility, count, viability and abnormal morphology in both human and animal sperm [17]. Wong et al. [18]. Show that antioxidants may be particularly important in protecting human sperm from peroxidative damage due to the high amount of poly-unsaturated fatty acids in sperm. Akinloye et al. [19] examined the selenium status of idiopathic infertile Nigerian males. In this study, selenium concentrations in the sera and seminal plasma of 60 infertile males ( 40 oligospermia and 20 azoospermia) and 40males with proven evidence of fertility (normospermia; control group) were estimated by atomic absorption spectrophotometry.

Table 1: Changes in semen parameters before and after treatment with selenium.

\begin{tabular}{|c|c|c|c|}
\hline Parameters & Before\$ & After\$ & $\%$ Increase \\
\hline Sperm count Million/ml & $39.24 \pm 27.4$ & $* 58.1 \pm 21.6$ & $32.70 \%$ \\
\hline Sperm motility \% & $22.14 \pm 12.9$ & $* 50.7 \pm 17.6$ & $56.30 \%$ \\
\hline Sperm viability $\%$ & $32.14 \pm 12.2$ & $* 60 \pm 19.1$ & $46.40 \%$ \\
\hline Normal Sperm morphology \% & $68 \pm 5.7$ & $* 82.1 \pm 6.4$ & $17.10 \%$ \\
\hline Ejaculate volume ml & $2.2 \pm 0.57$ & $* 3.61 \pm 0.32$ & $39 \%$ \\
\hline
\end{tabular}

$\$=$ mean $+/$ standard deviation $*=(p<0.01)$

The results of the study were correlated with spermatogram and hormonal levels in order to determine their relationship to male infertility. The mean serum concentrations of selenium were found to be significantly higher in cases of oligospermia when compared to cases of azoospermia and a significant inverse correlation was also observed between serum selenium levels and sperm count. It was also observed that seminal plasma selenium levels correlated with sperm motility, viability and morphology.
However, in a double-blind study of infertile men with reduced sperm motility, supplementation with selenium (100 mcg per day for three months) significantly increased sperm motility [20]. Low selenium in testis appears to underlie the impaired male fertility. Selenium is essential for spermatogenesis [21]. A deficiency of selenium in the diet results in increased oxidative stress negatively affecting spermatogenesis [22].

Table 2: Changes in seminal plasma element before and after treatment with selenium.

\begin{tabular}{|c|c|c|c|}
\hline Semen Parameters & Before Ttreatment\$ & After Treatment\$ & \% Increase \\
\hline $\mathrm{Zn}(\mu \mathrm{g} / \mathrm{dl})$ & $44.43 \pm 7.0$ & $* 68.55 \pm 5.4$ & $35.10 \%$ \\
\hline $\mathrm{Mg}(\mu \mathrm{g} / \mathrm{dl})$ & $25.57 \pm 2.2$ & $* 33.5 \pm 2.83$ & $23.60 \%$ \\
\hline $\mathrm{MDA}(\mu \mathrm{mol} / \mathrm{l})$ & $5.812 \pm 0.296$ & $* 2.212 \pm 0.35$ & $61.6 \% \downarrow$ \\
\hline Glutathione $(\mu \mathrm{mol} / \mathrm{l})$ & $8.27 \pm 1.34$ & $* 12.01 \pm 1.04$ & $31.1 \% \uparrow$ \\
\hline
\end{tabular}

$\$=$ mean $+/-$ standard deviation $*=(p<0.01)$

In another study, 69 infertile Scottish men were given either selenium or selenium in combination with vitamins A, C and E for three months. At the end of the clinical trial, all the patients showed significant improvements in sperm motility [20]. While Lerda reported that selenium by itself protected against oxidative DNA damage in human sperm thereby enhancing sperm motility and viability [23]. While (Table 2), Show that there are a high significant of semen zinc $\& \mathrm{Mg}$, parameters post-treated in each infertile men compared to pre-treatment. The high significant values are due to the effectiveness each treatments.

The MDA was decreased significantly after treatment with selenium. In a study conducted by Keskes- Ammar et al. [24] it was observed that vitamin $\mathrm{E}$ and selenium supplementation significantly decreased malondialdehyde (MDA) \& increase glutathione concentrations in infertile men. Table 3 shows that serum zinc concentration was not significantly increased of 
infertile men after treatment with selenium $0.837 \pm 0.11$ comparing this increment with the levels before treatment $0.61 \pm 0.12$ with a recorded increments of up to $27.1 \%$. In regard the serum $\mathrm{Mg}$ concentrations, they were significantly $(p<0.01)$ increased in patients treated by selenium $19.43 \pm 2.03$ as compared with before treatment $15.22 \pm 2.9$. The study observe an increase in serum $\mathrm{Mg}$ up to $21.6 \%$.

Table 3: changes in serum element before and after treatment with selenium.

\begin{tabular}{|c|c|c|c|}
\hline Serum Parameters & Before Treatment\$ & After Treatment\$ & \% Increase \\
\hline $\mathrm{Zn}(\mu \mathrm{g} / \mathrm{dl})$ & $0.61 \pm 0.12$ & $0.837 \pm 0.11$ & $27.10 \%$ \\
\hline $\mathrm{Mg}(\mu \mathrm{g} / \mathrm{dl})$ & $15.22 \pm 2.9$ & $* 19.43 \pm 2.03$ & $21.60 \%$ \\
\hline $\mathrm{MDA}(\mu \mathrm{mol} / \mathrm{l})$ & $5.55 \pm 0.75$ & $* 2.398 \pm 0.47$ & $56.70 \%$ \\
\hline Glutathione $(\mu \mathrm{mol} / \mathrm{l})$ & $7.398 \pm 0.68$ & ${ }^{*} 10.61 \pm 0.42$ & $30.20 \%$ \\
\hline
\end{tabular}

$\$=$ mean + - standard deviation $*=(p<0.01)$

Table 4: Changes in serum hormonal levels before and after treatment with selenium.

\begin{tabular}{|c|c|c|c|}
\hline Serum Parameters & Before Treatment\$ & After Treatment\$ & \% Increase \\
\hline FSH mlU/ml & $5.24 \pm 1.22$ & $* 7.83 \pm 0.88$ & $33 \%$ \\
\hline Serum $\mathrm{LH} \mathrm{mlU} / \mathrm{ml}$ & $5.22 \pm 0.63$ & $* 7.78 \pm 0.79$ & $32.90 \%$ \\
\hline testosterone $\mathrm{ng} / \mathrm{ml}$ & $8.58 \pm 1.73$ & $* 11.23 \pm 0.9$ & $23.50 \%$ \\
\hline
\end{tabular}

$\$=$ mean $+/$ standard deviation $*=(\mathrm{p}<0.01)$

The testosterone, FSH \& LH are increase significantly after treatment with selenium. It was also observed that serum selenium levels showed a positive correlation with serum testosterone levels (Table 4). The authors concluded that selenium appears to have a positive influence on Leydig cells, thus influencing the secretion of testosterone [19]. It also could be due to indirect effect mediated by increase level of serum zinc. Selenium is considered to be essential for normal spermatogenesis of mammals and the critical role it plays is principally mediated by two selenoproteins, namely Phospholipid Hydroperoxide Glutathione Peroxidase (PHGPX) and selenoprotein P. Laboratory evidence has shown that PHGPX is the major selenoprotein expressed by germ cells in the testis, having multiple functions and representing an important link between selenium, sperm quality and male fertility [21].

\section{References}

1. Wiersema N, Drukker A, Dung M (2006) Consequences of infertility in developing countries: results of a questionnaire and interview survey in the South of Vietnam. J Transl Med 4: 54.

2. Chaudhury K, DAS T, Chakravarly B, Bhattacharyya A (2005) Acrosin activity as a potential marker for sperm membrane characteristics in unexplained male infertility. Fertile Steril 83(1): 104-109.

3. Gracia CR, Sammel MD, Coutifaris C, Guzick DS, Barnhart KT (2005) Occupational Exposures and Male Infertility. Am J Epidemiol 162(8): 729-733.

4. Philippov OS, Radionchenko AA, Bolotova VP, Voronovskaya NI, Potemkina TV (1998) Estimation of the prevalence and causes of infertility in western Siberia. Bull World Health Organ 76(2): 183-187.

5. De Lamirande E, Gagnon C (1995) impact of reactive oxygen species on spermatozoa; a balancing act between beneficial and detrimental effects. Hum Repord 10(supply 1): 15-21.

6. Sies H (1993) Strategies of antioxidant defence. Eur J Biochem 215(2): 213-219.

7. Janero DR (1990) “Malondialdehyde and thiobarbituric acid reactivity as diagnostic indices of lipid peroxidation and per oxidative tissue injury". Free Radic Biol Med 9(6): 515-540.
8. Beckett GJ,Hayes JD (1993) Glutathione S-transferases: biomedical applications. Adv Clin Chem 30: 281-380.

9. Shan XQ, Aw TY, Jones DP (1990) Glutathione-dependent protection against oxidative injury. Pharmacol Ther 47(1): 61-71.

10. Stoltenberg M, Ernst E, Andreasen A (1996) Histochemical localization of zinc ions in the epididymis of the rat. The Histochemical Journal 28(3): 173-185.

11. Gavella M, Lipovae V (1998) In vitro effect of zinc on oxidative changes in human semen. Andrologia 30(6): 317-323.

12. Nair N, Bedwal S, Prasad S, Saini MR, Bedwal RS (2005) Short-term zinc deficiency in diet induces increased oxidative stress in testes and epididymis of rats. Indian J Exp Biol Sep 43(9): 786-794.

13. Maiorino M, Flohe L, Roveri A, Steinert P, Wissing JB (1999) Selenium and reproduction. Bio Factors 10: 251-256.

14. Griffin E, Wilson D (1994) Disorders of the testes. In: Isselbacher K, Braunwald E, Wilson J and Martin B (Eds.), Harrison's Principles of Internal Med. (13 edn), New York, McGraw Hill, USA.

15. Beckett GJ, Arthur JR, Millier SM, McKenzie RC (2004) Minerals and immune responses-selenium in diet and human immune function. (Eds). DA Hughes, LG Darlington, A Bendich, WR Beisel, Totora, Humana Press, United States, pp. 217-240.

16. Hurst R, Bao YP, Ridley S (1999) Phospholipid hydroperoxide cysteine peroxidase activity of human serum albumin. Biochem J 338(pt 3): 723-728.

17. Lewis SE, Sterling ES, Young IS, Thompson W (1997) Comparison of individual antioxidants of sperm and seminal plasma in fertile and infertile men. Fertil Steril 67(1): 142-147.

18. Wong WY, Thomas CM, Merkus JM, Zielhuis GA, Steegers-Theunissen RP (2000) Male factor subfertility: possible causes and the impact of nutritional factors. Fertil Steril 73(3): 435-442.

19. Akinloye O, Arowololu AO, Shittu OB, Adejuwon CA, Osotimehin B (2005) Selenium status of idiopathic infertile Nigerian males. Biol Trace Ele Res 104(1): 9-18.

20. Scott R, MacPherson A, Yates RW, Hussain B, Dixon J (1998) The effect of oral selenium supplementation on human sperm motility. Br J Urol 82(1): 76-78. 
21. Ursini F, Heim S, Kiess M, Maiorino M, Roveri A (1999) Dual function of the selenoprotein PHGPx during sperm maturation. Science 285(5432): 225-228

22. Shalini S, Bansal MP (2005) Role of selenium in regulation of spermatogenesis: involvement of activator protein 1. Biofactors 23(3): 151-162.
23. Lerda D (1992) Study of sperm characteristics in persons occupationally exposed to lead. Am J Ind Med 22(4): 567-571.

24. Keskes Ammar L, Feki Chakroun N, Rebai T, Sahnoun Z, Ghozzi H, et al (2003) Sperm oxidative stress and the effect of an oral vitamin E and selenium supplement on semen quality in infertile men. Arch Androl 49(2): 83-94.

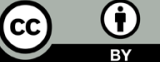

Creative Commons Attribution 4.0 International License

For possible submissions Click Here

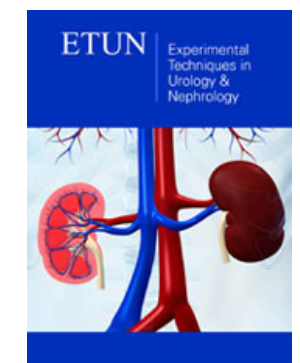

Experimental Techniques in Urology \& Nephrology

\section{Benefits of Publishing with us}

- High-level peer review and editorial services

- Freely accessible online immediately upon publication

- Authors retain the copyright to their work

- Licensing it under a Creative Commons license

- Visibility through different online platforms 